\title{
KILKA UWAG NA TEMAT KSIAZŻKI O. DARIUSZA WIŚNIEWSKIEGO EUROPA I ISLAM W ŚREDNIOWIECZU. KONFRONTACJA I WSPÓŁŻYCIE
}

\author{
Wojciech Mruk
}

Uniwersytet Jagielloński w Krakowie

\author{
ABSTRACT \\ SOME COMMENTS ON FR. DARIUSZ WIŚNIEWSKI'S BOOK \\ EUROPA I ISLAM W ŚREDNIOWIECZU. KONFRONTACJA

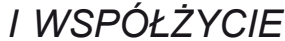

Fr. Dariusz Wiśniewski has prepared a book on the confrontation bewteen and coexistence of Latin Christians and Muslims in the Middle Ages. As we can read in the introduction, the book is addressed not only to scholars but to a wide spectrum of non-professional readers as well. In fact, the author managed to present some aspects of the very complicated and still actual problem of cross-religion relations in a way that can meet the expectations of more demanding readers. $\mathrm{He}$ pointed out and explained some of the most important consequences of the development and expansion of Latin and Muslim societies in the Mediterranean region before the fall of Acre in 1291. One may criticize the author's decision on the choice of the terminus ad quem. The collapse of the Crusader states in Outremer is not the most important turning point in the history of the relations between the Latin Christians and Muslims in the Middle Ages. Thus, we can treat Fr. Dariusz Wiśniewski's book as an interesting and inspiring, but definitely not final, voice in the important and still open discussion on this intriguing problem of medieval history.

Key words: Christians, Muslims, history, confrontation, coexistence, Middle Ages.

Słowa kluczowe: chrześcijanie, muzułmanie, historia, konfrontacja, współżycie, wieki średnie.

${ }^{1}$ D. Wiśniewski, Europa i islam w średniowieczu. Konfrontacja i wspótżycie, Poznań 2016, s. 184.

Adres do korespondencji: wojciech.mruk@uj.edu.pl 
Książka o. Dariusza Wiśniewskiego podejmuje bardzo ciekawy i niezwykle skomplikowany problem relacji pomiędzy chrześcijańską Europą a światem islamu w wiekach średnich. Już sam tytuł, niewątpliwie nawiązujący do znanej Autorowi pracy Franca Cardiniego, ale uzupełniony podtytułem niosącym odmienną niż u włoskiego badacza treść, wskazuje na zasadniczy cel książki, którym jest ukazanie relacji chrześcijańsko-muzułmańskich przez pryzmat zarówno konfrontacji, jak i współżycia ${ }^{2}$. Jak zostało wskazane we Wstępie, jednym z zamierzeń pracy było przedstawienie kontaktów i wymiany pomiędzy łacinnikami a muzułmanami w sposób pozwalający dowartościować kulturowe i teologiczne aspekty wzajemnych relacji (s. 11). Inspiracją do takiego ujęcia tematu stały się dla Autora jego wcześniejsze studia nad poglądami Rogera Bacona, wielkiego franciszkańskiego myśliciela, który w XIII stuleciu przedstawił własny, niezmiernie interesujący pomysł na rozwiązanie problemu relacji między wyznawcami obu wielkich religii. Rozważania, co również wyraźnie sprecyzowano, zostały ograniczone do problemu kontaktów pomiędzy chrześcijanami łacińskimi a muzułmanami w okresie do upadku państw krzyżowców w Outremer, czyli do roku 1291. Publikacja, choć w zamyśle Autora ma mieć charakter popularny, niewątpliwie zasługuje na uwagę, jako że wiele spośród przedstawionych w niej obserwacji i wniosków znacznie wykracza poza granicę, ,popularnych opinii".

Będące zasadniczą treścią książki trudne relacje międzykonfesyjne zostały ukazane na bardzo szerokim tle historycznym. W pierwszym rozdziale przedstawiono formowanie się tożsamości europejskiej, w założonym rozumieniu tego słowa, czyli budowanie odrębności politycznej, religijnej i kulturowej przez społeczności, które wyrosły na gruzach zachodnich prowincji cesarstwa rzymskiego. Jak wskazano w pracy, złożyły się na nią dziedzictwo tradycji imperialnej w połączeniu z religią chrześcijańską i przyniesionymi przez ludy germańskie strukturami społecznymi i rozwiązaniami militarnymi. Przedstawione zostały również wybrane wydarzenia, procesy i cechy, które decydowały o specyfice średniowiecznej łacińskiej Europy, takie jak narodziny świeckiego władztwa papieży oraz konsekwencje przenikania się sfer sacrum i profanum w życiu publicznym, aktywność misyjna Kościoła łacińskiego czy wreszcie rosnąca wśród duchownych i świeckich świadomość odrębności świata łacińskiego. Do uformowania się tego poczucia przyczyniła się między innymi ekspansja islamu, z którą przyszło się zmierzyć Europejczykom.

Narodzinom tej wielkiej i dynamicznie rozwijającej się religii został poświęcony drugi rozdział pracy. Przedstawiono w nim sytuację społeczno-religijną na Półwyspie Arabskim przed wystąpieniem Mahometa, życie i działalność Proroka oraz podstawowe zasady głoszonej przez niego wiary. Podkreślona została również specyfika funkcjonowania społeczności muzułmańskiej, dla której sfery sacrum i profanum stanowią nierozerwalną jedność. Wskazane zostały także pierwsze konflikty w łonie ummy i podziały na tle polityczno-religijnym. Osobny podrozdział poświęcono

\footnotetext{
${ }^{2}$ Książka Franca Cardiniego zatytułowana Europa a islam. Historia nieporozumienia, której polskie tłumaczenie ukazało się w Krakowie w 2006 r., przedstawia problem relacji między łacińską Europą a światem islamu w znacznie dłuższym okresie, a jednocześnie koncentruje się na historii wzajemnych konfliktów, mniej uwagi poświęcając pokojowej współpracy obu społeczności.
} 
różnym znaczeniom terminu dżihad i sposobom wypełniania tej powinności przez muzułmanów. Problem ten, zwłaszcza w obecnej sytuacji, jest nadal bardzo aktualny i ciągle budzi żywe emocje.

W rozdziale trzecim przedstawiono kolejne etapy ekspansji islamu oraz warunki polityczne i społeczno-religijne, w jakich ona postępowała. Omówione zostały spowodowane wojnami trudności polityczne i społeczne, tak w Bizancjum, jak i w Persji. Podkreślono także konsekwencje napięć religijnych wywołanych przez spory chrystologiczne, które istotnie osłabiły możliwości obronne Cesarstwa. W kolejnych podrozdziałach ukazano najważniejsze etapy podboju Syrii, Mezopotamii i Iranu oraz Egiptu i północnej Afryki. Następnie omówiono podbój terenów Półwyspu Iberyjskiego, pierwsze operacje na wodach Morza Śródziemnego i próby zdobycia Konstantynopola oraz walki o opanowanie Sycylii, a także zdobycie przyczółków na Półwyspie Apenińskim. W podsumowaniu tego rozdziału znalazła się również próba wskazania przyczyn nie tylko spektakularnych sukcesów militarnych, które pozwoliły muzułmanom rozciągnąc swoje panowanie polityczne na bardzo rozległych obszarach, ale również analiza przyczyn utrwalenia ich dominacji. Jak zostało to wyraźnie podkreślone, przyczyn tych sukcesów należy szukać zarówno w determinacji i zapale religijnym wojowników, jak i w roztropnej polityce ich przywódców wobec ludności podbitej, dla której nadejście muzułmanów nie musiało się wiązać ze zniszczeniem ich dotychczasowego świata.

Rozdział czwarty zatytułowany Reakcja Zachodu został podzielony na trzy podrozdziały. W pierwszym przedstawiono zarys dziejów toczącej się do schyłku XV stulecia rywalizacji militarnej muzułmanów i chrześcijan na Półwyspie Iberyjskim oraz jej bezpośrednich konsekwencji społecznych i demograficznych. W kolejnym podrozdziale noszącym tytuł Normanowie na Sycylii opisane zostały przesilenia polityczne wśród muzułmanów w północnej Afryce mające wpływ na sytuację na Sycylii. Przedstawiono w nim również konsekwencje pojawienia się na Półwyspie Apenińskim Longobardów, a następnie interwencji władców frankijskich, których plany polityczne obejmowały między innymi nawiązanie kontaktów dyplomatycznych z abbasydzkimi kalifami z Bagdadu. Omówione zostały także podejmowane przez Stolicę Apostolską próby zorganizowania koalicji zdolnych do wyparcia muzułmanów z ich przyczółków na Półwyspie. Wreszcie ukazane zostały okoliczności pojawienia się Normanów oraz ich podboje w Italii i na Sycylii. Trzeci z podrozdziałów przeznaczony został na opisanie narodzin wśród łacińskich chrześcijan idei świętej wojny oraz okoliczności ogłaszania i przebiegu kolejnych wypraw krzyżowych na Wschód. Przedstawione zostały w nim także konsekwencje polityczne i ideologiczne krucjat, tak dla łacinników, jak i dla muzułmanów.

Piąty rozdział nosi tytuł Życie codzienne w spoleczeństwie wielokulturowym i składa się $\mathrm{z}$ dwóch podrozdziałów. Omówiono w nich dwa modele relacji pomiędzy chrześcijanami i muzułmanami na obszarach, gdzie obie wspólnoty musiały funkcjonować $\mathrm{w}$ granicach jednego organizmu politycznego. W pierwszym, zatytułowanym Warunkowa tolerancja, przedstawiono religijno-prawne uwarunkowania stosunku muzułmanów do chrześcijan mieszkających w ich państwach oraz ukształtowane pod wpływem tych regulacji relacje między wyznawcami obu religii. Poruszono też problem funkcjonowania wspólnot muzułmańskich pod 
rządami chrześcijan. W drugim podrozdziale noszącym tytuł Eskalacja represji opisane zostały prześladowania, jakie stały się udziałem dobrowolnych męczenników $\mathrm{w}$ al-Andalus oraz chrześcijan $\mathrm{w}$ kalifacie fatymidzkim za panowania al-Hakima na początku XI stulecia. Wskazano też przypadki represji, które spadły na muzułmańskich mieszkańców Sycylii w drugiej połowie XII stulecia, a następnie za panowania na wyspie Fryderyka II Sztaufa.

W rozdziale szóstym zatytułowanym Średniowieczna orientalistyka i podzielonym na trzy podrozdziały przedstawiono ewolucję postrzegania islamu oraz jego wyznawców przez chrześcijan zachodnich. Postępowała ona wraz z pogłębianiem się wiedzy o muzułmanach, Mahomecie i zasadach islamu. Początkowo poznawano je przez pryzmat relacji chrześcijańskich autorów żyjących na Wschodzie, a dopiero $\mathrm{z}$ czasem zaczęto czerpać wiedzę z bezpośrednich kontaktów. W podrozdziale pierwszym przywołano między innymi dość powszechne wśród autorów wczesnego średniowiecza przekonanie o bliskich związkach między obu religiami, które skłaniało do uznawania islamu za jedną herezji wyrosłych na gruncie chrześcijaństwa. W drugim z podrozdziałów opisane zostały działania podjęte przez opata z Cluny Piotra Czcigodnego, który w połowie XII stulecia doprowadził do przetłumaczenia na łacinę Koranu i szeregu innych pism autorów muzułmańskich, dając tym samym łacinnikom narzędzia do lepszego poznania tej religii. Podrozdział trzeci poświęcony został przedstawieniu opinii na temat islamu wyrażonych przez wybranych autorów chrześcijańskich aktywnych w XIII stuleciu.

Zatytułowany Dziedzictwo cywilizacji islamskiej rozdział siódmy przeznaczony został na omówienie roli, jaką muzułmanie odegrali w przechowaniu osiągnięć intelektualnych świata antycznego. Opisano w nim, jak dzięki utworzonym w świecie islamu instytucjom naukowym przetłumaczono na język arabski, który stał się znakomitym narzędziem wymiany intelektualnej na rozległym obszarze kontrolowanym przez muzułmanów, znaczną część dorobku wcześniejszych cywilizacji. Tym samym możliwa stała się fuzja osiągnięć świata hellenistycznego, Persji, Indii i Chin. W kolejnych podrozdziałach przedstawiono rolę, jaką odegrali muzułmanie w zachowaniu i rozwoju nauk ścisłych, przyrodniczych i medycyny, a także filozofii i teologii. Wskazane zostały też ich zasługi w rozpowszechnieniu osiągnięć w zakresie rzemiosł, handlu czy kultury rolnej. Podkreślono również, że w kręgach wykształconych i bogatych muzułmanów rozwinęły się potrzeby estetyczne, których zaspokajanie zaowocowało rozwojem literatury i innych dziedzin twórczości artystycznej. W ostatnim podrozdziale omówiona została działalność ośrodków translatorskich, w których budzące żywe zainteresowanie zapóźnionej cywilizacyjnie Europy osiągnięcia intelektualne i artystyczne muzułmanów tłumaczono na łacinę.

W rozdziale ósmym, noszącym tytuł Wojna czy misja przedstawione zostały trzy wyróżnione przez Autora postawy łacińskich chrześcijan wobec problemu ułożenia relacji ze wspólnotą muzułmańską, która zgodnie z misyjnym powołaniem wyznawców Chrystusa powinna zostać objęta działaniami ewangelizacyjnymi. W trzech podrozdziałach przedstawiono kolejno: formowanie się koncepcji świętej wojny i opinie zwolenników wykorzystania jej jako podstawowego narzędzia ewangelizacji muzułmanów, poglądy autorów postulujących prowadzenie aktywnych i starannie przygotowanych działań misyjnych towarzyszących presji militarnej wywieranej 
na wyznawców Allaha i wreszcie opinie przeciwników zarówno samych krucjat, jak i sięgania po jakiekolwiek rozwiązania siłowe. Szczególnie cenne są w tym rozdziale rozważania na temat roli, jaką w XIII wieku odegrali mendykanci w realizowanych wówczas planach krucjatowych oraz misyjnych.

W zakończeniu - poza podsumowaniem wcześniejszych rozważań i podkreśleniem aktualności poruszonego problemu relacji między łacinnikami i muzułmanami - Autor wskazał dwa kolejne problemy badawcze związane z poruszonym w książce zagadnieniem. Są to relacje pomiędzy muzułmanami a Bizancjum (czy szerzej wschodnim chrześcijaństwem) oraz kwestia relacji łacinników i muzułmanów w późnym średniowieczu.

Ze wszech miar zasadnym uzupełnieniem tekstu jest sześć prostych, ale przejrzystych map, na których przedstawiono Półwysep Arabski oraz obszary, gdzie dochodziło do opisywanych kontaktów pomiędzy łacinnikami a muzułmanami. Cennym dodatkiem, zwłaszcza dla czytelnika niebędącego specjalistą, jest też obejmująca kilkadziesiąt pozycji wybrana bibliografia problemu, w której wymieniono między innymi najważniejsze dostępne $\mathrm{w}$ języku polskim prace poświęcone relacjom chrześcijańsko-muzułmańskim w wiekach średnich.

Jak wynika z przedstawionego omówienia, książka o. Dariusza Wiśniewskiego, mimo zadeklarowanego we wstępie popularnego charakteru, jest dziełem znacznie bardziej ambitnym. Zamysł przedstawienia relacji między łacińską Europą a światem islamu w okresie wczesnego i pełnego średniowiecza należy uznać za jak najbardziej uzasadniony i to nie tylko bieżącą sytuacją polityczną. Jest to rzeczywisty i poważny problem badawczy, który, mimo iż od wielu lat przyciąga uwagę uczonych, nadal daje możliwości kolejnych dociekań i nowych interpretacji, czego przykładem jest omawiana książka. Pochwalić należy również zamiar ukazania tych relacji w szerokim kontekście dziejów politycznych oraz przeobrażeń kulturowych, religijnych i społecznych. Bez zrozumienia tego tła nie jest możliwa żadna poważniejsza analiza tak skomplikowanego zagadnienia.

Próba przedstawienia, w niewielkiej objętościowo publikacji, tak szerokiego problemu, który poddano analizie na wielu płaszczyznach, wymagała dokonania szeregu uzasadnionych skrótów i uproszczeń. Mimo to wiele zawartych w pracy spostrzeżeń i wniosków zasługuje na uznanie, a udostępnienie ich szerokiemu odbiorcy jest ze wszech miar uzasadnione. Dotyczą one na przykład unifikującej roli islamu, czynników sprzyjających utrwaleniu władzy muzułmanów na rozległych obszarach zamieszkanych przez różne wspólnoty etniczne i religijne czy przeobrażeń ideologicznych, jakim ulegało łacińskie społeczeństwo w trakcie i pod niewątpliwym wpływem rywalizacji chrześcijańsko-muzułmańskiej. Walor poznawczy ma także ukazanie niejednoznaczności przekazu koranicznego dotyczącego stosunku muzułmanów do chrześcijan czy wieloznaczności terminu dżihad. Podobnie jest w przypadku rozdziału ósmego omawiającego różnorodne postawy chrześcijan wobec wyznawców islamu i planów ich nawrócenia. Zawarte w nim konstatacje, zilustrowane właściwie dobranymi cytatami ze źródeł, sprawiają, że te fragmenty książki niewątpliwie przekraczają merytorycznie ramy publikacji o charakterze popularnym.

O ile część przyjętych w książce ograniczeń obszarów badawczych jest w pełni uzasadniona, dotyczy to nawet decyzji o ukazaniu wzajemnych relacji głównie 
z perspektywy strony chrześcijańskiej, to inne wydają się dyskusyjne. Uznanie za granicę chronologiczną prowadzonych rozważań załamania się państw krzyżowców w Outremer jest trudne do zaakceptowania. Wydarzenia, które rozegrały się wokół roku 1291, odegrały niewątpliwie ważną rolę w relacjach politycznych między chrześcijanami łacińskimi i muzułmanami we wschodniej części basenu Morza Śródziemnego, ale dla innych obszarów, na których trwała polityczna konfrontacja międzykonfesyjna - na przykład na Półwyspie Iberyjskim - nie były one tak istotne. Co więcej, tworzone po roku 1291 plany działań charakterze konfrontacyjnym nie odbiegały zasadniczo od podobnych projektów z okresu wcześniejszego. Analiza tekstów, których autorami byli między innymi Piotr Dubois (De recuperatione Terrae Sanctae z 1306 r.), Marino Sanuto Torsello (Secreta fidelium crucis, pierwsza wersja z 1307 r.) czy Wilhelm Adam (De modo Saracenos extirpandi z 1311 r.), dowodzi, że większość postulatów dotyczących przygotowań i przebiegu zbrojnej wyprawy na Wschód formułowanych przed upadkiem Akki, na przykład przez przywołanego w pracy Fidencjusza z Padwy, czy jeszcze wcześniej w postanowieniach soboru laterańskiego IV (zawarcie pokoju między łacinnikami, powołanie skutecznego dowództwa, zachowanie przez krzyżowców właściwej postawy moralnej, wykorzystanie presji ekonomicznej, zasiedlanie łacinnikami zdobywanych terenów itp.), była powtarzana w okresie późniejszym, oczywiście przy uwzględnieniu zmienionej z powodu upadku państw krzyżowców sytuacji geopolitycznej ${ }^{3}$. Podobnie było w przypadku autorów, którzy kładli nacisk na połączenie presji militarnej z działaniami misyjnymi, co doskonale widać $\mathrm{w}$ datowanych na początek XIV wieku pismach Ramona Lulla (w Liber de fine z 1305 r., a zwłaszcza w Liber de acquisitione Terrae Sanctae z 1309 roku, gdzie proponował skoordynowanie działań militarnych na Wschodzie z operacjami zbrojnymi na Półwyspie Iberyjskim) ${ }^{4}$.

Również dla konfrontacji na płaszczyźnie ideologicznej upadek panowania Franków w Syrii trudno uznać za punkt zwrotny. Nie oznaczał on bowiem żadnej poważnej zmiany w stosunku do muzułmanów i ich religii. Powstające w pierwszej połowie XIV stulecia pisma autorów chrześcijańskich poruszające problemy relacji ze światem

${ }^{3}$ Fidentio de Padua, Liber recuperationis Terrae Sanctae, wyd. G. Golubovich [w:] Biblioteca bio-bibliografica della Terra Santa e dell'Oriente francescano, t. 2, Quaracchi 1913, s. 26-59; Decreta Generalis Concilii Lateranensis IV, ed. J.D. Mans i, Sacrorum conciliorum nova et amplissima collectio, t. XXII, Venetia 1778, col. 1058-1067; P. Dubo is, De recuperatione Terre Sancte, publié d'après manuscrit du Vatican par Ch.V.-Langlois, Paris 1891, s. 1-140; W.I. Brandt, Pierre Dubois: Modern or Medieval, „The American Historical Review” 1930, t. 35, nr 3, s. 510-517; P. L o ck, The Routledge Companion to the Crusades, London-New York 2006, s. 124-125; S. Runciman, Dzieje wypraw krzyżowych, t. III, Królestwo Akki i późniejsze krucjaty, Warszawa 1988, s. 398-400; A.S. At iy a, Crusade, Commerce and Culture, Bloomington 1962, s. 95, 97; idem, The Crusade in the Later Middle Ages, London 1938, s. 37-103; Guillelmus Adae, De modo Saracenos extirpandi [w:] Recueil des historiens croisades, Documents armeniens, ed. Ch. Ko hl er, t. II, Paris 1906, s. 521555; S. S chein, Fideles Crucis: The Papacy, the West and the Recovery of the Holy Land 1274-1314, Oxford 1991, s. 269-270.

${ }^{4}$ G. Ens eny at, Pacifism and Crusade in Ramon Llull, „Quaderns de la Mediterrània” 2008, t. 9 , s. 137, 141-142; A. S a w i ck a, Działalność Rajmunda Llulla na rzecz dialogu z islamem [w:] Krucjata bez krucjat. O franciszkanach na ziemiach islamu, red. A. Zaj ą c OFMConv, Kraków 2011, s. 128-131; P. L o ck, op. cit., s. 125. 
islamu nie odbiegają zasadniczo od podobnych dzieł tworzonych przed upadkiem Akki. Franciszkanin Odoryk, który w swym dziele Liber de Terra Sancta zamieścił rozdział De Machometo, w zasadzie powtórzył znane z tekstów wcześniejszych opinie niechętne Prorokowi i wyznawcom głoszonej przez niego religii ${ }^{5}$. Podobną niechęć połączoną z daleko idącą ignorancją widzimy także u anonimowego pielgrzyma z Kolonii (pisał ok. roku 1340) oraz współczesnego mu dominikanina Piotra de Pennis ${ }^{6}$.

Gdy przeanalizujemy drugi aspekt relacji chrześcijańsko-muzułmańskich, czyli wspólżycie, rok 1291 również trudno uznać za moment przełomowy, nawet w przypadku Ziemi Świętej (rozumianej na sposób średniowieczny, czyli od Egiptu po północną Syrię) $)^{7}$. Łacińscy chrześcijanie, jeszcze w okresie przedkrucjatowym, decydowali się na osiedlanie się na terenach kontrolowanych przez muzułmanów i godzili się na status mniejszości religijnej o ograniczonych prawach. Byli to zarówno kupcy prowadzący interesy w miastach portowych Egiptu i Syrii, jak i osoby związane z łacińskimi instytucjami kościelnymi i charytatywnymi, które niosły posługę duchową i pomoc materialną łacińskim pielgrzymom odwiedzającym Ziemię Świętą ${ }^{8}$. Utworzenie państw krzyżowców zasadniczo, ale tylko na krótki okres i na ograniczonym, kontrolowanym przez Franków obszarze, zmieniło sytuację łacinników. Stali się oni grupą dominującą politycznie oraz uprzywilejowaną prawnie i religijnie. Jednocześnie cały czas stanowili znikomą mniejszość etniczną i wyznaniową żyjącą w świecie zdominowanym przez muzułmanów i chrześcijan obrządków wschodnich 9 . Wojny krzyżowców z muzułmanami postawiły obie strony wobec konieczności ułożenia na nowo zasad współżycia w okresie po zakończeniu walk. Bolesne doświadczenia

5 Od oryk, Odorici de Foro Iulii Liber de Terra Sancta, ed. J.C.M. La u rent [w:] Peregrinatores medii aevi quatuor, ed. J.C.M. La u re n t, Lipsiae 1864, s. 157-158.

${ }^{6}$ Anonymus Coloniensis, ed. R. Röhricht, H. Meisner, Ein Niederrheinscher Bericht über den Orient, „Zeitschrift für deutsche Philologie” 1887 (1886), XIX, s. 8-23, 27-31. Petrus de Pennis (O.P.), Tractatus contra Alchoranum, cap. I-XV, maszynopis przygotowany w $2016 \mathrm{r}$. przez F. González-Muñoz, s. 1-50; Ch. Kohler, Le Libellus de Locis ultramarinis de Pierre „,de Pennis” O.S.D., „Revue de l'Orient Latin” 1902, vol. IX, s. 313-314.

7 Był to obszar obiecany Abrahamowi przez Boga: „[kraj] od Rzeki Egipskiej aż do rzeki wielkiej, rzeki Eufrat" (Rdz 15, 18).

${ }^{8}$ Nasir Khusraw, Sefer Namèh, Relation du voyage de Nassiri Khosrau en Syrie, en Palestine, en Égypte, en Arabie et en Perse, pendant les années de l'Hégire 437-444 (1035-1042), publié, traduit et annoté par Ch. S c he fe r, Paris 1881 s. 41, 66-67; Mukadd a s i, Description of Syria including Palestine by Mukaddasi (Circ. 985 A.D.), transl. and annot. by G. Le Strange, London 1886, s. 37; M. Can ard, Les Relations Politiques et Sociales Entre Byzance et les Arabes, „Dumbarton Oaks Papers" 1964, t. 18, s. 52-53; M. Gabriele, An Empire of Memory: The Legend of Charlemagne, the Franks, and Jerusalem before the First Crusade, Oxford 2011, s. 27, 34; D.F. Call a h a n, Al-Hakim, Charlemagne, and the Destruction of the Church of the Holy Sepulcher in Jerusalem in the Writings of Ademar of Chabannes [w:] The Legend of Charlemagne in the Middle Ages. Power, Faith and Crusades ed. by M. Gabriele, J. Stuckey, New York 2008, s. 41-49; H.C. Krueger, The Italian Cities and the Arabs before 1095 [w:] A History of the Crusades, ed. K.M. S etto n, vol. I, The First Hundred Years, ed. M.W. B aldw in, Madison Milwaukee, London 1969, s. 40-53; S. R un c i m a n, The Pilgrimages to Palestine before 1095 [w:] A History of the Crusades..., t. I, s. 68-78; L.B. Rob bert, Venice and the Crusades [w:] A History of Crusades..., t. V, The Impact of the Crusades on the Near East, ed. N.P. Z a c o ur, H.W. Ha z a d, Madison 1985, s. 394-395.

9 J.C. Rus s e 11, The Population of the Crusader States [w:] A History of Crusades ..., t. V, s. 308-309; H.S. Fink, The Foundation of the Latin States 1099-1118 [w:] A History of the Crusades..., t. I, s. 369. 
niewątpliwie potęgowały wzajemną nieufność, ale pierwsze próby ułożenia relacji w nowych post-krucjatowych warunkach widzimy już w końcu XII wieku, kiedy to muzułmanie odzyskali znaczne obszary, w tym i Jerozolimę ${ }^{10}$. Od tego czasu status łacińskich społeczności w Egipcie i Syrii był regulowany między innymi bilateralnymi traktatami pomiędzy władcami muzułmańskimi i siłami politycznymi chrześcijańskiej Europy. Układy takie wielokrotnie zawierali monarchowie europejscy (na przykład Ryszard Lwie Serce w 1192 r., Fryderyk II Sztauf w 1229 r. czy Alfons III Aragoński w 1290 r.), ale także wielkie republiki kupieckie (na przykład Wenecja, która zawarła szereg układów w latach 1205-1217 czy Genua w 1290 r.) ${ }^{11}$. Upadek państw krzyżowców nie przyniósł w tej materii zasadniczych zmian ${ }^{12}$.

$\mathrm{O}$ ile założenie przedstawienia opisu konfrontacji i współżycia z perspektywy strony chrześcijańskiej uzasadnia ograniczenie do minimum analizy zmiany stosunku muzułmanów do łacinników na przestrzeni wieków średnich, to znacznie trudniej zaakceptować daleko idące ograniczenie omówienia problemu ewolucji stosunku dominujących politycznie chrześcijan do ich muzułmańskich poddanych. Co prawda w Outremer wyznawcy Allaha już od pierwszych lat istnienia państw krzyżowców cieszyli się niemal nieograniczoną swobodą religijną, ale sytuacja wspólnot niechrześcijańskich w państwach łacińskiej Europy w ciągu XIII stulecia wyraźnie się zmieniała ${ }^{13}$. Od początku tego wieku można zaobserwować rosnącą presję wywieraną przez chrześcijan pragnących doprowadzić do konwersji wszystkich mniejszości wyznaniowych. Zjawisko to miało wiele przyczyn. Niewątpliwie jednak dominującą rolę odegrały tu przemiany w świadomości religijnej ówczesnych łacińskich społeczności, które w obliczu wyzwań wywołanych aktywnością grup heretyckich stanęły wobec konieczności precyzyjnego wyznaczenia granicy swój-obcy na płaszczyźnie religijnej i jednocześnie uznały za konieczne zintensyfikowanie dążeń do osiągnięcia jedności wyznaniowej ${ }^{14}$. Załamanie władztwa Franków w Outremer w roku 1291 nie miało większego wpływu na te procesy.

${ }^{10} \mathrm{~W}$ wyniku operacji prowadzonych przez Saladyna do roku 1188 Frankowie utracili niemal całe Królestwo Jerozolimskie, a rezultatem III krucjaty była tylko częściowa restytucja ziem. S. R u n c i m a n, Dzieje..., t. III, s. 17-81.

11 P.M. Holt, Early Mamluk Diplomacy (1260-1290): treaties of Baybars and Qalāwūn with Christian rulers, Leyden-New York-Köln, 1995, passim; L.B. R o b b e rt, op. cit., s. 441-443.

12 P.M. Holt, Bliski Wschód od wypraw krzyżowych do 1517 roku, Warszawa 1993, s. 188-192.

13 J. Prawer, The Settlement of the Latins in Jerusalem, „Speculum” 1952, t. 27, nr 4, s. 490491; idem, Social Classes in the Crusader States: the „Minorities” [w:] A History of Crusades..., t. V, s. 100, 105; M. Na de r, Urban Muslims, Latin Laws, and Legal Institutions in the Kingdom of Jerusalem, „Medieval Encounters” 2007, t. 13, z. 2, s. 243-246; B.Z. Ke d a r, Crusade and Mission: European Approaches toward the Muslims, Princeton 1984, s. 118-119; J. Ochman, Średniowieczna filozofia żydowska, Kraków 1995, s. 60-200; J.F. O’ Calla g ha n, A History of Medieval Spain, Ithaca-London 1975, s. 519; W. Mruk, Ziemia Święta w oczach rabina Izaaka Chelo (XIV wiek) [w:] Portolana, Studia Mediterranea, t. 2: Religie świata śródziemnomorskiego, red. D. Qu i r in i-P opław s ka, Kraków 2006, s. 176; A. Vauchez, Chrześcijanie wobec niechrześcijan [w:] Historia chrześcijaństwa, t. V: Ekspansja Kościoła rzymskiego1054-1274, red. J.-M. May er, Ch. Pietri, L. Pietri, A. Vauchez, M. Venard, J. Kło c zow s ki, Warszawa 2001, s. 580-589.

14 J. Chélin i, Dzieje religijności w Europie Zachodniej w średniowieczu, Warszawa 1996, s. 276278; A. Vauchez, op. cit., s. 580-589. 
Trudno znaleźć również uzasadnienie dla pominięcia, ważnego z punktu widzenia głównego problemu pracy, zagadnienia relacji pomiędzy chrześcijanami i muzułmanami, w których zasadnicze linie podziałów i sojuszy nie pokrywały się z granicami religijnymi. Doskonałym przykładem mogą być tu na przykład sojusz króla Jerozolimy Fulka z Unurem z Damaszku skierowany przeciw Zankiemu, układy Ferdynanda II Kastylijskiego z muzułmanami wymierzone w Alfonsa I Portugalskiego czy wreszcie porozumienia Wenecjan z Ajjubidami, w których poddani Serrenissimy zobowiązywali się, że ich flota nie udzieli wsparcia krzyżowcom ${ }^{15}$.

Przywołany przykład aktywności dyplomatycznej Republiki Świętego Marka każe zastanowić się nad zasadnością pominięcia w omawianej książce kolejnego ważnego aspektu wspólżycia między chrześcijanami i muzułmanami, jakim były kontakty handlowe. Począwszy od XII stulecia, były one jednym z fundamentalnych czynników wpływających na wzajemne relacje obu wspólnot i to bardzo często na przekór podziałom religijnym. Spektakularnym przykładem są tu chociażby gwarancje bezpieczeństwa i swobód działalności handlowej zaoferowane europejskim kupcom przez Saladyna po zdobyciu Akki, i to w chwili, w której cały czas prowadził operacje zbrojne przeciw krzyżowcom ${ }^{16}$.

Poza wskazanymi wyżej pominięciami wątpliwości budzi również konstrukcja jednego z podrozdziałów w rozdziale czwartym poświęconym reakcji Zachodu na ekspansję islamu. W części zatytułowanej Normanowie na Sycylii poruszono szereg wątków wykraczających poza treść sugerowaną w tytule (np. istotny problem zaangażowania Karolingów w Italii, kontaktów dyplomatycznych Karola Wielkiego z Harunem ar-Raszidem czy interwencji politycznych i militarnych podejmowanych w Italii przez Bizancjum). Jednocześnie trudno rozpatrywać aktywność Normanów w południowej Italii i na Sycylii wyłącznie przez pryzmat reakcji Zachodu na podboje wyznawców islamu. Zaangażowanie się wojowników z Północy w działania na tym obszarze było rezultatem splotu wielu różnych okoliczności, dość poprawnie opisanych $\mathrm{w}$ omawianym podrozdziale, zaś ich operacje przeciwko muzułmanom prowadzone były równolegle $\mathrm{z}$ działaniami wymierzonymi w chrześcijańskich Bizantyńczyków i Longobardów ${ }^{17}$. Dlatego też w przypadku tego fragmentu pracy możemy mówić o zbyt daleko idącym uproszczeniu.

${ }^{15}$ H.A.R. Gibb, Zengi and the Fall of Edessa [w:] A History of the Crusades..., t. I, s. 459-460; A.H. de Olive ir a Marque s, Historia Portugalii, t. I: Do XVII w., Warszawa 1987, s. 59; H.E. Ma y er, Historia wypraw krzyżowych, Kraków 2008, s. 150-151; S. Runciman, Dzieje..., t. III, s. 243-244; M. B alard, Eaciński Wschód XI-XV wiek, Kraków 2010, s. 226-227; W.B. S teven s on, The Crusaders in the East. A brief History of the Wars of Islam with the Latins in Syria During the Twelfth and Thirteenth Centuries, Cambridge 1907, s. 325; J. Praw er, Histoire du royaume latin de Jérusalem, Paris 1975, t. II, s. 326-327, 330; G. B i s soli, La Repubblica di Venezia e la Custodia di Terra Santa [w:] La Custodia di Terra Santa e l'Europa. I rapporti politici e l'attività culturale dei Francescani in Medio Oriente, a cura di M. Pic cirillo, Roma 1983, s. 84; A. Maalouf, Wyprawy krzyżowe w oczach Arabów, Warszawa 2001, s. 236; D. Qu i rin i-Popła w s k a, Znaczenie Republiki Weneckiej we wschodniej części basenu Morza Śródziemnego na przetomie XII/XIII w. [w:] eadem, Italia mia. Studia z dziejów Italii i powiazań polsko-włoskich w późnym Średniowieczu i Renesansie, Kraków 2016, s. $247-248$.

16 T. A s bri d ge, Krucjaty. Wojna o Ziemię Święta, Kraków 2015, s. 335-336.

${ }_{17}$ R.A. Brow n, Historia Normanów, Gdańsk 1996, s. 79-113. 
Dokonanie szeregu skrótów i pewnego rodzaju uproszczeń podczas omawiania niezwykle złożonej i przedstawianej na wielu, zasadnie dobranych, płaszczyznach analizy relacji chrześcijańsko-muzułmańskich jest w pewnym stopniu uzasadnione. Próba zaprezentowania pełnej, wyczerpującej wszystkie wątki syntezy zaowocować mogłaby bowiem stworzeniem znacznie bardziej obszernego dzieła, które siłą rzeczy byłoby adresowane do wąskiego grona specjalistów. Tym samym zamiar dotarcia do szerszego kręgu odbiorców zapewne nie zostałby zrealizowany.

Nie sposób jednak nie zauważyć, że część spośród przedstawionych w publikacji sądów jest na tyle mało precyzyjna, iż może prowadzić niemającego profesjonalnego przygotowania czytelnika do błędnych wniosków. Przykładem tego typu uproszczeń mogą być początkowe fragmenty rozdziału pierwszego. Na stronie 13 możemy przeczytać między innymi:

Od połowy III wieku barbarzyńskie hordy coraz częściej przekraczały limes antycznego świata i coraz głębiej penetrowały terytorium pax romana. Te najazdy nie wynikały z przyczyn religijnych czy politycznych, jak to później miało miejsce w przypadku inwazji arabskiej, lecz były następstwem fascynacji wysoką kulturą i poziomem życia mieszkańców Zachodu.

Tak lapidarne przedstawienie problemu przenikania ludów barbarzyńskich na tereny imperium sprawia, że czytelnik nie widzi różnicy pomiędzy pokojowym napływem germańskich imigrantów, którzy na różne sposoby budowali swoją przyszłość w ramach struktur cesarstwa (np. podejmując służbę w rzymskiej armii), a zbrojnymi najazdami i przełamywaniem słabo bronionych granic ${ }^{18}$. Co więcej, można dojść do wniosku, że do tych wielkich wędrówek ludów nie przyczyniły się żadne czynniki polityczne. Fragment ten zdaje się również umniejszać znaczenie czynników ekonomicznych, które popychały biednych beduinów do najazdów na bogate krainy. $\mathrm{Z}$ kolei na stronie 25, przy opisie formowania się struktur władzy po śmierci Mahometa, Abu Bakr został nazwany ,następcą Mahometa w roli przewodniczącego rytualnej modlitwy", nie pojawił się natomiast tytuł kalifa i wyjaśnienie jego znaczenia. Nie wspomniano o nim również przy omawianiu specyfiki funkcjonowania struktur władzy formującego się państwa muzułmańskiego. Znalazło się tam jedynie enigmatyczne zdanie „Przywódca jako najwyższy autorytet zarządzał wspólnotą muzułmańską i podejmował decyzje zarówno w kwestiach administracyjno-sądowych, jak i religijno-doktrynalnych" (s. 26). Sam tytuł kalifa pojawia się oczywiście przy imionach poszczególnych władców. Dwuznaczny jest również fragment: „W przeciwieństwie do innych regionów cesarstwa chrześcijanie w Iberii [tu w znaczeniu: na Półwyspie Iberyjskim] dość szybko osiągnęli porozumienie w kwestii różnic doktrynalnych. Na synodzie kościelnym w Toledo w 589 r. ariańscy Wizygoci przyjęli katolicką naukę większości mieszkańców” (s. 47). Można się z nim zgodzić jedynie wtedy, gdy za punkt odniesienia przyjmiemy niechalcedońskie Kościoły Wschodu.

${ }^{18}$ M. Wilczyńs ki, Gocja czy Romania? Migracje Wizygotów, Wandalów i Burgundów w Vw. n.e. i stosunek ich władców do administracji i ludności rzymskiej [w:] Wędrówka i etnogeneza w starożytności $i$ wśredniowieczu, red. M. S a la mo n, J. S trzelczy k, Kraków 2010, s. 173-191. 
Wizygoci bowiem, na tle innych arian osiedlających się na gruzach zachodnich prowincji cesarstwa, wyjątkowo długo trwali przy swej odrębności wyznaniowej i próbowali nakłonić do konwersji swych katolickich poddanych ${ }^{19}$. Sformułowana na stronie 80 definicja krucjaty jako „ogłoszonej przez papieża wyprawy militarnej, która stawiała sobie za cel wyzwolenie Grobu Chrystusa z rąk muzułmanów" jest, zwłaszcza dla omawianego w pracy XIII stulecia, uproszczeniem wypaczającym obraz ruchu krucjatowego w tym okresie ${ }^{20}$. W innym miejscu, na stronie 84 można przeczytać: „Wyrazem łacińskiej dominacji i niezależności od Bizancjum było powołanie patriarchatów Kościoła rzymskiego w Antiochii i Jerozolimie". Czytelnik nieznający skomplikowanej sytuacji formalnej i faktycznej obu patriarchatów, które w chwili przybycia krzyżowców istniały już od stuleci, może odnieść mylne wrażenie, że to łacinnicy stali za ich utworzeniem ${ }^{21}$. Daleko idącym uproszczeniem jest również stwierdzenie: „Do Królestwa Jerozolimskiego jako lenna zależne należały księstwo Antiochii, hrabstwo Edessy i hrabstwo Trypolisu" (s. 84). Problem wzajemnych zależności tak instytucjonalnych, jak i osobistych pomiędzy poszczególnymi organizmami i ich władcami jest niezmiernie złożony i dlatego też kategoryczne twierdzenie, że w Outremer powstało jedno „państwo krzyżowców”

19 J. Strzelc zy k, Goci-rzeczywistość i legenda, Warszawa 1984, s. 213-223.

${ }^{20}$ Wiek XIII był okresem niezwykłego wprost ożywienia ruchów krucjatowych. Wyprawy podejmowane były nie tylko do Ziemi Świętej, w różnorodne działania wspierające krucjaty udało się zaś zaangażować szerokie masy społeczeństwa europejskiego - nie tylko wojowników. S.A. Throop, Crusading as an Act of Vengeance, 1095-1216, Farnham 2011, s. 117-119; W.B. Stevenson, op. cit., s. 296, 301-302; H.E. Mayer, op. cit., s. 317, 343, 347-348, 351-352; P.M. Holt, Bliski Wschód..., s. 79; G.Z. Gray, The Children's Crusade. An Episode of the Thirteenth Century, BostonNew York, 1898, s. 14; M. B a lar d, op. cit., s. 214-215; C.R. Co nd er, The Latin Kingdom of Jerusalem. 1099 to 1291 A.D., London 1897, s. 306; A. La gard e, The Latin Church in The Middle Ages, New York 1915, s. 487-488; G. Minois, Kościót $i$ wojna. Od czasów Biblii do ery atomowej, Warszawa 1998, s. 115-116; Ch.T. Mai e r, Preaching the Crusades. Mendicant Friars and thr Cross in the Thirteenth Century, Cambridge Studies in Medieval Life and Thought, $4^{\text {th }}$ Series, 28, Cambridge 1998, s. 62, 107-108, 124; J. Rile y - S mith, Mentalność krzyżowców na Wschodzie 1095-1300 [w:] Historia krucjat, red. J. Ril e y-S m it h, Warszawa 2000, s. 96; S. L1 o y d, Ruch krucjatowy 1096-1274 [w:] Historia krucjat..., s. 62-63; N. Hou sle y, The Thirteenth-century Crusades in the Mediterranean [w:] The New Cambridge Medieval History, red. D. A bu l a fi a, Cambridge 2006, t. V, s. 573; N. Ho u s le y, The Crusades and Islam, „Medieval Encounters” 2007, t. 13, s. 201-202; D.P. Wa le y, Papal Armies in the Thirteenth Century, „The English Historical Review” 1957, t. 72, nr 282, s. 1-15; J.M. P ow e11, Church and Crusade: Frederick II and Louis IX, „The Catholic Historical Review” 2007, t. XCIII, nr 2, s. 253-254; N. Housley, The Thirteenth-century Crusades in the Mediterranean [w:] The New Cambridge Medieval History..., t. V, s. 572; J.A. Watt, The Papacy [w:] The New Cambridge Medieval History..., t. V, s. 120.

${ }^{21}$ G. Troupeau, Kościoly $i$ chrześcijanie na obszarze Wschodu muzulmańskiego [w:] Historia chrześcijaństwa, t. 4, red. J.-M. May er, Ch. Pietri, L. Pietri, A. Va u chez, M. Ven ard, Warszawa 1999, s. 330; K. Kościelniak, Grecy i Arabowie. Historia Kościoła melkickiego (katolickiego) na ziemiach zdobytych przez muzutmanów (634-1516), Kraków 2004, s. 20, 217, 239; J. H arris, Bizancjum $i$ wyprawy krzyżowe, Warszawa 2005, s. 116; J. R i c hard, La Papauté et les missions d'Orient au Moyen Âge (XIII -XVe siècles), Collection de l'école française de Rome 33, Roma 1998, s. 9; idem, The Political and Ecclesiastical Organization of the Crusader States [w:] A History of the Crusades..., t. V, s. 233, 236, 238; J.M. N e l e, A History of the Holy Eastern Church. The Patriarchate of Antioch, London 1873, s. 3. 
jest nieuprawnione ${ }^{22}$. Podobnie mało precyzyjne jest twierdzenie, że stryj Saladyna (w pracy nie wymieniono imienia Szirkuha) stał się panem Egiptu na skutek podboju (s. 85). Jak wiemy, jego pojawienie się nad Nilem było efektem porozumienia pomiędzy Nur ad-Dinem a pragnącym odzyskać pozycję wezyrem Szawarem ${ }^{23}$. Te i inne podobne uproszczenia oraz niezręczne sformułowania nie powinny się znaleźć w książce adresowanej do szerszego kręgu odbiorców, jako że mogą one prowadzić do wyciągania błędnych wniosków.

Obok wspomnianych wyżej uproszczeń czy pominięć w pracy znaleźć można sformułowania na tyle nieprecyzyjne, że zdają się przekraczać granice poprawności merytorycznej. Tak jest na przykład w przypadku nazwania patriarchy Jerozolimy Sofroniusza „greckim patriarchą" (s. 36). W przededniu nadejścia muzułmanów Jerozolima była w pełni suwerenną stolicą, zaś sam Sofroniusz pochodził z Damaszku² ${ }^{24}$.

Jak podkreślono wcześniej, poruszony w książce problem jest niewątpliwie godny uwagi, zaś zamysł ukazania relacji między chrześcijanami z łacińskiej Europy a muzułmanami na tak szerokim tle jest w pełni uzasadniony. Plan stworzenia pracy adresowanej do szerokiego kręgu odbiorców również zasługuje na uznanie ze względu na wagę i aktualność omawianego tematu. Niestety wskazane powyżej usterki sprawiają, ze lektura pracy pozostawia czytelnika z uczuciem niedosytu. Obok fragmentów napisanych w sposób barwny i jednocześnie niosących wiele ciekawych i umiejętnie dobranych informacji (zwłaszcza w rozdziałach szóstym i ósmym) znalazły się akapity ze sformułowaniami mało precyzyjnymi, które mogą kierować odbiorcę, zwłaszcza niebędącego profesjonalistą, w stronę błędnych wniosków. Podobne rezultaty przynieść może pominięcie w pracy części istotnych, wskazanych powyżej, wątków chrześcijańsko-muzułmańskich relacji. Dokonując oceny książki, należy mieć oczywiście świadomość tego, że każda decyzja o ograniczeniu bądź uproszczeniu wywodu może być uznana za kontrowersyjną. $Z$ drugiej wszakże strony dążenie do przedstawienia pełnego i kompletnego obrazu tak skomplikowanego zagadnienia oznaczałoby prawdopodobnie znaczne powiększenie objętości publikacji, a tym samym odebrało jej znaczną część waloru popularności. Dlatego też należy uznać książkę o. Dariusza Wiśniewskiego za ciekawą i godną uwagi pozycję wydawniczą, która porusza ważny problem, przynosi szereg ciekawych konstatacji, a jednocześnie pozostawia miejsce dla kolejnych prac, które mogą ją uzupełnić i przedstawić bardziej precyzyjny i kompletny obraz relacji chrześcijańsko-muzułmańskich w wiekach średnich.

${ }^{22}$ H.S. Fink, op. cit., s. 409; J.L. La M on te, Monarchia feudalna w tacińskim Królestwie Jerozolimskim w latach 1100-1291, Oświęcim 2015, s. 174-186; M. B a la rd, op. cit., s. 83-112.

${ }^{23}$ M.C. Ly o n s, D.E.P. J a c k s o n, Saladyn, Polityka świętej wojny, Warszawa 2006, s. 13-40.

${ }^{24}$ P. A1le n, Sophronius of Jerusalem and Seventh Century Heresy. The Synodical Letter and Other Documents, Oxford 2009, s. 16; K. Ko ści eln i ak, op. cit., s. 52-54, 99-100. 


\section{BIBLIOGRAFIA}

Allen P., Sophronius of Jerusalem and Seventh Century Heresy. The Synodical Letter and Other Documents, Oxford 2009.

Anonymus Coloniensis, red. R. Röhricht, H. Meisner, Ein Niederrheinscher Bericht über den Orient, „Zeitschrift für deutsche Philologie” 1887 (1886), t. XIX.

A s bridge T., Krucjaty. Wojna o Ziemię Święta, Kraków 2015.

A ti y a A.S., Crusade, Commerce and Culture, Bloomington 1962.

A ti y a A.S., The Crusade in the Later Middle Ages, London 1938.

B a lard M., Laciński Wschód XI-XV wiek, Kraków 2010.

B is soli G., La Repubblica di Venezia e la Custodia di Terra Santa [w:] La Custodia di Terra Santa e l'Europa. I rapporti politici e l'attività culturale dei Francescani in Medio Oriente, a cura di M. Piccirillo, Roma 1983.

Brandt W.I., Pierre Dubois: Modern or Medieval, „The American Historical Review” 1930, t. 35, nr 3.

Brown R.A., Historia Normanów, Gdańsk 1996.

Callah an D.F., Al-Hakim, Charlemagne, and the Destruction of the Church of the Holy Sepulcher in Jerusalem in the Writings of Ademar of Chabannes [w:] The Legend of Charlemagne in the Middle Ages. Power, Faith and Crusades, red. M. Gabriele, J. S tu ckey, New York 2008.

C a n ard M., Les Relations Politiques et Sociales Entre Byzance et les Arabes, „Dumbarton Oaks Papers" 1964, t. 18.

Chél in i J., Dzieje religijności w Europie Zachodniej w średniowieczu, Warszawa 1996.

Conder C.R., The Latin Kingdom of Jerusalem. 1099 to 1291 A.D., London 1897.

Decreta Generalis Concilii Lateranensis IV, red. J.D. M a n s i, „Sacrorum conciliorum nova et amplissima collectio", t. XXII, Venetia 1778.

En se ny at G., Pacifism and Crusade in Ramon Llull, „Quaderns de la Mediterrània” 2008, t. 9.

Fidentio de Padua, Liber recuperationis Terrae Sanctae, wyd. G. Golubovich [w:] Biblioteca bio-bibliografica della Terra Santa e dell'Oriente francescano, t. 2, Quaracchi 1913.

F in k H.S., The Foundation of the Latin States 1099-1118 [w:] A History of the Crusades, red. K.M. Sett on, t. I: The First Hundred Years, red. M.W. B aldw in, Madison, Milwaukee-London 1969.

Gabriele M., An Empire of Memory. The Legend of Charlemagne, the Franks, and Jerusalem before the First Crusade, Oxford 2011.

Gib b H.A.R., Zengi and the Fall of Edessa [w:] A History of the Crusades, red. K.M. S e tto n, t. I: The First Hundred Years, red. M.W. B aldw in, Madison, Milwaukee-London 1969.

Gray G.Z., The Children's Crusade. An Episode of the Thirteenth Century, Boston-New York 1898.

Guillelmus Adae, De modo Saracenos extirpandi [w:] Recueil des historiens croisades, Documents armeniens, red. Ch. Kohler, t. II, Paris 1906.

Harris J., Bizancjum i wyprawy krzyżowe, Warszawa 2005.

Holt P.M., Bliski Wschód od wypraw krzyżowych do 1517 roku, Warszawa 1993.

Holt P.M., Early Mamluk Diplomacy (1260-1290): treaties of Baybars and Qalāwūn with Christian rulers, Leyden-New York-Köln 1995. 
Ho u sley N., The Crusades and Islam, „Medieval Encounters” 2007, t. 13.

Hou sley N., The Thirteenth-century Crusades in the Mediterranean [w:] The New Cambridge Medieval History, red. D. A bu l a fi a, t. V, Cambridge 2006.

Ke d a r B.Z., Crusade and Mission: European Approaches toward the Muslims, Princeton 1984.

Kohler Ch., Le Libellus de Locis ultramarinis de Pierre „, de Pennis” O.S.D., „Revue de l'Orient Latin" 1902, t. IX.

Kości elniak K., Grecy i Arabowie. Historia Kościoła melkickiego (katolickiego) na ziemiach zdobytych przez muzulmanów (634-1516), Kraków 2004.

Krueger H.C., The Italian Cities and the Arabs before 1095 [w:] A History of the Crusades, red. K.M. S e t t o n, t. I: The First Hundred Years, red. M.W. B ald w in, Madison, Milwaukee-London 1969.

La Monte J.L., Monarchia feudalna $w$ tacińskim Królestwie Jerozolimskim $w$ latach 1100-1291, Oświęcim 2015.

La gard e A., The Latin Church in The Middle Ages, New York 1915.

Lloyd S., Ruch krucjatowy 1096-1274 [w:] Historia krucjat, red. J. Riley-Smith, Warszawa 2000.

L o ck P., The Routledge Companion to the Crusades, London-New York 2006.

Ly on s M.C., J a c k s o n D.E.P., Saladyn, Polityka świętej wojny, Warszawa 2006.

Ma a louf A., Wyprawy krzyżowe w oczach Arabów, Warszawa 2001.

Maier Ch.T., Preaching the Crusades. Mendicant Friars and the Cross in the Thirteenth Century, Cambridge Studies in Medieval Life and Thought, $4^{\text {th }}$ Series, 28, Cambridge 1998.

Ma ye r H.E., Historia wypraw krzyżowych, Kraków 2008.

M in o is G., Kościót i wojna. Od czasów Biblii do ery atomowej, Warszawa 1998.

Mruk W., Ziemia Święta w oczach rabina Izaaka Chelo (XIV wiek) [w:] Portolana, Studia Mediterranea, t. 2: Religie świata śródziemnomorskiego, red. D. Quirini-P opław s ka, Kraków 2006.

Mukaddasi, Description of Syria including Palestine by Mukaddasi (Circ. 985 A.D.), transl. and annot. by G. Le Strange, London 1886.

$\mathrm{N}$ ade r M., Urban Muslims, Latin Laws, and Legal Institutions in the Kingdom of Jerusalem, „Medieval Encounters” 2007, t. 13, z. 2.

Nas ir Khusraw, Sefer Namèh, Relation du voyage de Nassiri Khosrau en Syrie, en Palestine, en Égypte, en Arabie et en Perse, pendant les années de l'Hégire 437-444 (10351042), publié, traduit et annoté par Ch. S c he fer, Paris 1881.

N e a le J.M., A History of the Holy Eastern Church. The Patriarchate of Antioch, London 1873.

O ' C all a g ha n J.F., A History of Medieval Spain, Ithaca-London 1975.

O c h m an J., Średniowieczna filozofia żydowska, Kraków 1995.

Odoryk, Odorici de Foro Iulii Liber de Terra Sancta [w:] Peregrinatores medii aevi quatuor, red. J.C.M. La u rent, Lipsiae 1864.

Oliveira Marques A.H. de, Historia Portugalii, t. I: Do XVII w., Warszawa 1987.

Petrus de Pennis (O.P.), Tractatus contra Alchoranum, cap. I-XV, maszynopis przygotowany w roku 2016 przez F. G on zález-Muñoz, s. 1-50.

Pierre Dubois, De recuperatione Terre Sancte, publié d'après manuscrit du Vatican par Ch.-V. Langlo is, Paris 1891.

Powell J.M., Church and Crusade: Frederick II and Louis IX, „The Catholic Historical Review" 2007, t. XCIII, nr 2.

Praw e r J., Histoire du royaume latin de Jérusalem, Paris 1975.

Praw er J., The Settlement of the Latins in Jerusalem, „Speculum” 1952, t. 27, nr 4. 
Prawer J., Social Classes in the Crusader States: the „Minorities” [w:] A History of Crusades, red. K.M. Setton, t. V: The Impact of the Crusades on the Near East, red. N.P. Z a c o ur, H.W. Ha zard, Madison 1985.

Quirini-Popławska D., Znaczenie Republiki Weneckiej we wschodniej części basenu Morza Śródziemnego na przełomie XII/XIII w. [w:] D. Quirini-Popław ska, Italia mia. Studia z dziejów Italii i powiązań polsko-włoskich w późnym Średniowieczu i Renesansie, Kraków 2016.

Ri ch ard J., La Papauté et les missions d'Orient au Moyen Âge (XIII - XVE siècles), Collection de l'école française de Rome 33, Roma 1998.

Richard J., The Political and Ecclesiastical Organization of the Crusader States [w:] A History of the Crusades, red. K.M. S e t t o n, t. V: The Impact of the Crusades on the Near East, red. N.P. Z a c o u r, H.W. H a z ard, Madison 1985.

Riley-S mith J., Mentalność krzyżowców na Wschodzie 1095-1300 [w:] Historia krucjat, red. J. Riley-Smith, Warszawa 2000.

Robbert L.B., Venice and the Crusades [w:] A History of Crusades, red. K.M. S etton, t. V: The Impact of the Crusades on the Near East, red. N.P. Z a c o u r, H.W. Ha zard, Madison 1985.

Runciman S., Dzieje wypraw krzyżowych, t. III, Królestwo Akki i późniejsze krucjaty, Warszawa 1988.

Runciman S., The Pilgrimages to Palestine before 1095 [w:] A History of the Crusades, red. K.M. Setto n, t. I, The First Hundred Years, red. M.W. B aldw in, Madison Milwaukee, London 1969.

Russell J.C., The Population of the Crusader States [w:] A History of Crusades, red. K.M. S etto n, t. V, The Impact of the Crusades on the Near East, red. N.P. Z a c ou r, H.W. Hazard, Madison 1985.

S a w i cka A., Działalność Rajmunda Llulla na rzecz dialogu z islamem [w:] Krucjata bez krucjat. O franciszkanach na ziemiach islamu, red. A. Zaj ą c OFMConv, Kraków 2011.

S che in S., Fideles Crucis. The Papacy, the West and the Recovery of the Holy Land 12741314, Oxford 1991.

S teven son W.B., The Crusaders in the East. A brief History of the Wars of Islam with the Latins in Syria During the Twelfth and Thirteenth Centuries, Cambridge 1907.

Strzelczyk J., Goci-rzeczywistość i legenda, Warszawa 1984.

Thro op S.A., Crusading as an Act of Vengeance, 1095-1216, Farnham 2011.

Troupeau G., Kościoły i chrześcijanie na obszarze Wschodu muzutmańskiego [w:] Historia chrześcijaństwa, t. IV: Biskupi, mnisi i cesarze 610-1054, red. J.-M. Mayer, Ch. Pietri, L. Pietri, A. Va u chez, M. Ven ard, Warszawa 1999.

Va u che z A., Chrześcijanie wobec niechrześcijan [w:] Historia chrześcijaństwa, t. V: Ekspansja Kościoła rzymskiego 1054-1274, red. J.-M. Mayer, Ch. Pietri, L. Pietri, A. Vauchez, M. Ven ard, J. Kłoczow ski, Warszawa 2001.

Waley D.P., Papal Armies in the Thirteenth Century, "The English Historical Review" 1957, t. 72, nr 282.

Watt J.A., The Papacy [w:] The New Cambridge Medieval History, red. D. A bulafia, t. V, Cambridge 2006.

Wilczyński M., Gocja czy Romania? Migracje Wizygotów, Wandalów i Burgundów $w V$ w. n.e. i stosunek ich władców do administracji i ludności rzymskiej [w:] Wędrówka $i$ etnogeneza $w$ starożytności $i w$ średniowieczu, red. M. Sala mon, J. Strzelczyk, Kraków 2010. 